\title{
Sovjetski pogled na zbivanja u Hrvatskoj i Jugoslaviji u drugoj polovini 1950-ih i početkom 1960-ih
}

\author{
MATEUSZ SOKULSKI \\ Uniwersytet Śląski w Katowicach (Šlesko sveučilište u Katowicama) \\ Katowice, Poljska \\ mateuszsokulski@gmail.com
}

\begin{abstract}
U članku je analiziran sovjetski pogled na zbivanja u drugoj najvećoj jugoslavenskoj republici tijekom druge polovine 50 -ih i prve polovine 60 -ih godina. Uzeta je u obzir situacija u Jugoslaviji i međusobni odnosi Beograda i Moskve. Dosad su se povjesničari zanimali prije svega za političku dimenziju međusobnih odnosa i sovjetske ocjene političkoga stanja u Jugoslaviji. Iako su politika i ideologija bile u centru pozornosti sovjetskih diplomata, u članku nisu zanemarena ni kulturna zbivanja u Federativnoj Narodnoj Republici Jugoslaviji (od 1963. Socijalističkoj Federativnoj Republici Jugoslaviji) ni gospodarski položaj zemlje. Ove su dimenzije čvrsto povezivali s političkom sferom te podređivali sovjetskim interesima prema Jugoslaviji.

Članak je utemeljen na izvornoj arhivskoj građi prikupljenoj u Moskvi u Ruskom državnom arhivu novije povijesti (Российский государственный архив новейшей истории), u fondu Odjela za veze s komunističkim i radničkim partijama socijalističkih zemalja, koji je odgovarao za odnose sa zemljama komunističkoga uređenja. U radu je korištena i relevantna stručna literatura.
\end{abstract}

Ključne riječi: Sovjetski Savez; Hrvatska; Jugoslavija; ideologija; kultura; propaganda

\section{Uvodne napomene}

Politika Saveza Socijalističkih Sovjetskih Republika (SSSR) prema Jugoslaviji bitno se promijenila nakon Staljinove smrti u ožujku 1953. godine. U sklopu procesa destaljinizacije u SSSR-u i promjene odnosa sa satelitskim zemljama Srednje Europe Moskva je poduzela korake radi stabilizacije odnosa s Beogradom, čiji su rezultati bili Beogradska i Moskovska deklaracija iz 1955. i 1956. godine. Oba sporazuma trebala su odrediti oblik međudržavnih i međupartijskih odnosa Saveza komunista (SK) Jugoslavije i Komunističke partije Sovjetskoga Saveza (KPSS). ${ }^{1}$ Razvoj odnosa Beograda i Moskve nije značio

1 Tekstove Beogradske i Moskovske deklaracije vidi npr. u: PETRANOVIĆ, ZEČEVIĆ, Jugoslavija 1918-1988, 1042-1047. O stabilizaciji odnosa Jugoslavije i SSSR-a vidi: PELIKAN, 
da će SSSR odustati od pokušaja ponovnoga uključivanja Federativne Narodne Republike Jugoslavije / Socijalističke Federativne Republike Jugoslavije (FNRJ/SFRJ) u svoj lager. Sovjetski Savez neprestano je vršio pritisak na Jugoslaviju i težio uvlačenju te države u sferu svojega izravnog utjecaja. Postojeće tenzije uobličene su u osudu Jugoslavije na samitima komunističkih i radničkih partija 1957. i 1960., kao i negodovanje istočnoeuropskih komunističkih vođa zbog novoga programa SK Jugoslavije proglašenog na VII. kongresu SK Jugoslavije 1958., a tek 60-ih godina poboljšavaju se odnosi Jugoslavije i Sovjetskoga Saveza te se napetosti smanjuju. ${ }^{2}$

U sklopu međusobnih odnosa i radi vlastitih interesa u Kremlju se pažljivo promatrala i unutarnja situacija u Jugoslaviji. Važno mjesto u sovjetskom fokusu imala je i Narodna Republika (NR; od 1963. Socijalistička Republika - SR) Hrvatska. U totalitarnoj državi kakav je bio Sovjetski Savez svi segmenti političkoga i društvenoga života strogo su povezani, pa vrijedi skrenuti pozornost na izvještaje i prepisku diplomatsko-partijskih kadrova SSSR-a u vezi s FNRJ/SFRJ. Razdoblje druge polovine 50 -ih, pa i prve polovine 60-ih godina obilježeno je u Jugoslaviji daljnjim traganjem, započetim nakon konflikta s istočnim blokom 1948., za odgovarajućim rješenjima koja bi učvrstila unutarnjopolitičke specifičnosti i vanjskopolitičku orijentaciju jugoslavenskoga socijalističkog sustava. Sve veću ulogu imale su i republike zbog pitanja decentralizacije te rasprava o razini njihove samostalnosti. Zbog svojega gospodarskog potencijala i interesa prema ostalim republikama, jedna od najvažnijih republika bila je upravo Hrvatska. Razvoj gospodarstva, važni događaji poput Zagrebačkoga velesajma i kulturne pojave poput Praxisa imali su odjeka mnogo šire od granica Hrvatske. Stoga se vrijedi upustiti u analizu kako su zbivanja unutar zemlje, u samoj Hrvatskoj, vidjeli sovjetski službenici zastupajući globalne interese SSSR-a.

Dosadašnji najvažniji radovi o sovjetskoj politici prema Jugoslaviji posvećeni su prvom desetljeću nakon Drugoga svjetskog rata, koje zaokružuje Moskovska deklaracija iz 1956. godine. ${ }^{3}$ Pojedini i istraživački vrijedni radovi koji se tiču druge polovine 50 -ih i prve polovine 60 -ih godina nastajali su ili isključivo na osnovi materijala prikupljenih u Beogradu ${ }^{4}$ ili su važan, premda tek uvodni uvid u sovjetsku politiku prema Jugoslaviji ${ }^{5}$. Treba napomenuti da

Jugoslávie a východní blok; DIMIĆ, „Jugoslovensko-sovjetski odnosi 1953-1956: zbliženje, pomirenje, razočarenje”; ЕДЕМСКИЙ, От конфликта к нормализации.

2 TRIPKOVIĆ, Jugoslavija-SSSR 1956-1971, 93-98, 109-110.

3 Među najvažnijim radovima treba spomenuti one A. Edemskog (ЕДЕМСКИЙ, Om конфликта к нормализации), monografiju pod uredništvom A. Anikejeva Москва и Восточная Европа, zbornike dokumenata pod uredništvom Lj. Dimića Jugoslavija - SSSR. Susreti i razgovori na najvišem nivou rukovodilaca Jugoslavije i SSSR i Jugoslovensko-sovjetski odnosi 1945-1956, kao i rad G. Miloradovića Lepota pod nadzorom, koji sadržava zanimljive zaključke o stranim kulturnim utjecajima u Jugoslaviji te njihovoj apsorpciji.

4 TRIPKOVIĆ, Jugoslavija-SSSR 1956-1971.

5 ЕДЕМСКИЙ, “Нормализация отношений с СССР“, 661-682; СТЫКАЛИН, “СССРЮгославия: зигзаги двусторонних отношений“, 95-102. 
su povjesničari u manjoj mjeri istraživali pitanje unutarnje situacije, a više su istraživali međusobne diplomatske odnose. U radu su praćena pitanja politike, ideologije, gospodarstva, kulture i društvenoga života koja su za Sovjete bila bitna zbog procjena u kolikoj je mjeri jugoslavenski režim odudarao na društvenom planu od sovjetskoga. Nije manje važno ni pitanje koliki je sovjetski utjecaj na jugoslavensko društvo bio moguć u sklopu dalekosežnih interesa Moskve - širenja izravnoga utjecaja i kontrole širom Srednje Europe, koju su u odnosu prema Jugoslaviji političari u Kremlju uvijek imali na umu.

\section{Politika i ideologija}

Jugoslavenski je poredak bio blizak onima u satelitskim državama SSSR-a, odudarao je od zapadne prakse, a nakon raskida s Moskvom izgradio je načela svojstvena jugoslavenskome monopartijskom režimu. U načelu se svodio na monopartijski sustav uobličen u prevlasti komunista te je odudarao od demokratskih režima i načela. ${ }^{6} \mathrm{~S}$ druge strane jugoslavenski je režim bio posve udaljen od sovjetskoga, tretiranog u vladajućim krugovima SK Jugoslavije s nepovjerenjem.

Zbog toga su se $\mathrm{u}$ istočnom bloku pozorno promatrali potezi jugoslavenskih političara, a tijekom 1957. održani su republički partijski kongresi. Upravo onaj u NR Hrvatskoj privukao je najveću pozornost Moskve. Veleposlanik u Beogradu Ivan Zamčevskij naglasio je prisutnost najvažnijih funkcionara na federalnoj razini - Josipa Broza Tita, Edvarda Kardelja te Aleksandra Rankovića. Sovjetski diplomat istaknuo je da je šef Ministarstva unutarnjih poslova Jugoslavije izrazio negodovanje na račun kritike koju je Kremlj uputio Beogradu zbog odbojnosti jugoslavenskih političara prema pokušajima uvlačenja $\mathrm{u}$ istočni blok. Ranković je s uvjerenjem govorio o ispravnom putu vanjske politike FNRJ te ulozi tiska, koji bi, po njegovu mišljenju, trebao obrazlagati utemeljenost izabranih rješenja na vanjskom planu. Završna riječ pripala je Titu, koji je isključio bilo kakvu mogućnost povratka u istočni blok, naglasivši nezavisnu politiku zemlje, a istovremeno je govorio o opredjeljenju zemlje u smjeru „savjesti miroljubivih naroda”.

Srž tadašnjih partijskih kongresa Moskva je svodila na afirmaciju jugoslavenskoga režima i traženje legitimizacije omalovažavanjem sustava u istočnom bloku. Sadržaj nastupa tadašnjega potpredsjednika Sabora NR Hrvatske Nikole Sekulića 12. travnja 1957. Zamčevskij je u pismu ministru vanjskih poslova Dmitriju Šepilovu s negodovanjem opisao riječima: „Glavni sadržaj Sekulićeva govora odnosio se na ludo hvaljenje jugoslavenskoga puta socijalističkoga razvoja kao jedinoga ispravnog." Vlastita rješenja afirmiralo se, kako

6 MIHALJEVIĆ, „Ustavna uređenja temeljnih prava u Hrvatskoj”, 27, 31-32.

7 RU-РГАНИ, ф.5, оп. 49, д. 39, И.Замчевский, посольство СССР вСФРЮ в секретариат товарища Д. Т. Шепилова, Деятельност СКЮ в областиидеологическойработы, 22 мая 1957 г., 258-259. 
je izvještavao Zamčevskij, pojačanim pritiskom na medije preko izdavačkih vijeća, kao i na masovne organizacije, prije svega studentske. U vidu propagande naglašena je uloga medija, u čija su vijeća ušli vodeći političari. Veleposlanik je naveo primjer Borbe, u koju su radi većega prodora partijskoga programa u glasila ušli Veljko Vlahović i Mijalko Todorović. Zamčevskij je izvještavao: „Kritikom 'staljinizma' otvoreno se revidiraju osnovni principi marksizma-lenjinizma i poriče se univerzalno-povijesno sovjetsko iskustvo." Veleposlanik je napomenuo da je Sekulić u svojem referatu neprestano ponavljao da se jugoslavenske vlasti moraju suprotstaviti staljinizmu i „socijalističkim izopačenjima”. Potpredsjednik Sabora istaknuo je naime da se od 1948. Jugoslavija u pitanju shvaćanja „socijalističkoga internacionalizma” držala „ispravno”, a da je uvođenjem ideja poput samoupravljanja, sustava komuna te decentralizacije znatno pridonijela razvoju socijalizma kao univerzalne ideje. $^{8}$

Legitimizacija vlastitoga režima pokušavala se postići i pomoću raznih obljetnica, od kojih je najpogodnija bila 40. godišnjica boljševičke revolucije 1957. godine. Iako su sovjetski diplomati s negodovanjem gledali na tijek priprema i obilježavanje godišnjice boljševičkoga prevrata, smatralo se da je ta prilika pogodna za šire predstavljanje stava koji je zastupao KPSS. Naime, Kremlj je dotad propagandno mogao djelovati jedino preko Sovjetskoga kulturnog centra, a u vrijeme masovnoga pothvata u okviru organizacije obljetnice mnoge društvene i lokalne organizacije molile su sovjetske predstavnike da im daju materijale. Sovjetski službenici u Jugoslaviji smatrali su da opća prisutnost propagande vezane uz revoluciju može biti dobra za sovjetske inicijative. Prikazivanje filmova i izložbi koje do toga trenutka nisu napuštale zidove Sovjetskoga kulturnog centra stvaralo je priliku da se javnost preko materijala sovjetskoga podrijetla upozna sa sovjetskom politikom i da se eventualno dobije pozornost među jugoslavenskim državljanima. ${ }^{9}$

Početak 1957. obilježen je sve boljim odnosima Jugoslavije i SSSR-a, o čemu je svjedočilo zaustavljanje međusobnih napada u novinama, a vrhunac „razumijevanja” bio je susret prvoga sekretara SK Jugoslavije Josipa Broza Tita i KPSS-a Nikite Hruščova u Rumunjskoj u ljeto te godine. ${ }^{10}$ Od travnja 1957. ocijenjeno je u pismu savjetnika sovjetskoga veleposlanstva V. A. Brikina, obustavljene su polemike $\mathrm{u}$ tisku, poput onih iznijetih na spomenutom kongresu Centralnoga komiteta SK Hrvatske, na kojem je Nikola Sekulić navodio da se jedino Jugoslavija držala principa i da su „[...] Jugoslaveni se cijelo vrijeme borili ne samo protiv neprijatelja Sovjetskoga Saveza u vrijeme Drugoga svjetskog rata, ali i 'štitili su' ideale Listopadske revolucije od onih koji su 'izopačili socijalizam i tekovine Listopada"'. Veleposlanik Zamčevskij, koji je u

Isto, 254, 256.

9 RU-РГАНИ, ф. 5, оп. 49, д. 39, Б. Брыкин, Советник посольства СССР в СФРЮ, О подготовке в Югославии к празднованию 40-й годовщиныоктябьрскойреволюиии, 21 октябра 1957 г., 329-330.

10 TRIPKOVIĆ, Jugoslavija-SSSR 1956-1971, 68-72. 
svojim izvještajima bio mnogo kritičniji prema stavovima političara u FNRJ, s negodovanjem je primio takav stav, polazeći od uvjerenja da bi s obzirom na prisutnost i jak utjecaj katolicizma u Hrvatskoj u prvom redu trebalo privesti kritici „buržoaska shvaćanja” umjesto napada na Sovjetski Savez. ${ }^{11}$ Savjetnik veleposlanstva u Beogradu Brikin izvještavao je da su u organizacijski komitet formiran u studenom 1956. ušli najvažniji političari, a s obzirom na to da je početak priprema koincidirao s izbijanjem Mađarske revolucije, Jugoslaveni su ju kritikom režima $\mathrm{u}$ istočnom bloku kao izloženog krizama iskoristili za legitimizaciju vlastitoga režima. ${ }^{12}$ Zabilježeno je da se SR Hrvatska spremala organizirati priredbe povodom obljetnice u cijeloj zemlji, a na zagrebačkom Lenjinovu trgu (danas Trg kralja Petra Krešimira) pripremalo se postavljanje Lenjinova kipa. U program godišnjice uključili su se Muzej narodne revolucije te Povijesni arhiv, koji je namjeravao objaviti zbirku dokumenata posvećenih organizaciji izložbe na temu revolucije i tradicije radničkoga pokreta u Jugoslaviji. $^{13}$

U kontekstu priprema za obljetnicu boljševičkoga prevrata spomenuto je da je tijekom susreta poljske i jugoslavenske partijsko-vladine delegacije u studenom 1957. Tito naglasio važnost boljševičke revolucije i vodeće uloge SSSR-a u pogledu razvoja socijalizma, no istovremeno je istaknuo i „veću odgovornost Moskve pred progresivnim snagama” u pitanju održanja svjetskoga mira. ${ }^{14}$ Vrijedi napomenuti da je susret predstavnika NR Poljske i FNRJ u studenom 1957. u Beogradu doveo do jugoslavenskoga priznanja zapadne granice Poljske, što je prouzrokovalo prekid odnosa FNRJ i Savezne Republike Njemačke na osnovi Hallsteinove doktrine. Usprkos tome, u diplomatskim krugovima Beograda prevladavalo je zadovoljstvo što je sa zemljom istočnoga bloka postignuta deklaracija koja je sadržavala zapise o „različitim putevima izgradnje socijalizma" i nemiješanju u unutarnja pitanja druge države. ${ }^{15}$

$\mathrm{Na}$ propagandnom i kulturnom planu pojačana je aktivnost u brojnim publikacijama. U tisku su objavljivani članci jugoslavenskih sudionika revolucije, poput člana Saveznoga izvršnog vijeća Pavla Gregorića, predsjednika Republičkoga vijeća Skupštine NR Srbije Nikole Grulovića ili umirovljenoga oficira Dimitrija Georgijevića, samoga Josipa Broza Tita, kao i vođa komuni-

11 RU-РГАНИ, ф. 5, оп. 49, д. 39, И. Замчевскийпосольство СССР в СФРЮ в секретариаттоварища Д. Т. Шепилова, Деятельност СКЮ в областиидеологическойработы, 22 мая 1957 г., 256.

12 RU-РГАНИ, ф. 5, оп. 49, д. 39, Б. Брыкин, Советникпосольства СССР в СФРЮ, О подготовке в Югославии к празднованию 40-ц̆ годовщиньоктябьрскойреволюици, 21 октябра 1957 г., 320-321.

13 Isto, 325-326.

14 Isto, 322.

15 Više o Hallsteinovoj doktrini i njezinoj primjeni prema Jugoslaviji vidi u: TEBINKA, Uzależnienie czy suwerenność?, 117; NEĆAK, Hallsteinova doktrina i Jugoslavija; SR-AJ-507CKSKJ, Komisija za međunarodne odnose i veze, Poljska, IX, 101/I, dokument 127, Bilateralni odnosi političkih i društvenih organizacija. 
stičkih zemalja poput Mao Zedonga i Georgija Dimitrova. ${ }^{16} \mathrm{Na}$ kulturnom planu obilježavanje godišnjice odnosilo se na manifestacije u brojnim kazalištima. Na daskama Jugoslovenskoga dramskog pozorišta u Beogradu predstavljena je drama Oklopni vlak 14-69 prema pripovijesti Vsevoloda Ivanova, a u Beogradskom dramskom pozorištu Optimistička tragedija prema drami Vsevoloda Višnjevskog. Svečane priredbe bile su pripremljene i u Jugoslovenskoj kinoteci (poput filmova Lenjin u listopadu, Mi iz Kronštadta i dr.), ali veliko nezadovoljstvo izazvala je projekcija američkoga filma Od cara do Lenjina iz 1937. u režiji Hermana Axelbanka. Taj film radikalnih američkih umjetnika bio je izraz divljenja autora, u SSSR-u omraženom, Lavu Trockom. Zato se javno prikazivanje toga filma u sovjetskom veleposlanstvu smatralo izravnom provokacijom i pokušajem revizije revolucionarnih događaja. ${ }^{17}$

Najveće zamjerke izražene su pak na račun publikacija u kojima se, prema riječima Zamčevskog, na lažan način omalovažavalo djelovanje SSSR-a i zagovarao „revizionizam i oportunizam”. U sovjetskim izvještajima pojavile su se optužbe da je takav pristup SSSR-u izazvan školovanjem mnogih intelektualaca iz Jugoslavije na Zapadu nakon 1948. godine. Glavni primjer takvih shvaćanja bila je knjiga Borisa Ziherla Dijalektički i historijski materijalizam iz 1951. U vidu omalovažavanja slovenskoga filozofa iznošene su u izvještajima sovjetskoga veleposlanstva tvrdnje da se taj znanstvenik nije upustio u dublju ideološku analizu razvoja marksizma, ograničavajući se na kritike ideološke prakse komunizma u SSSR-u. Među drugim publikacijama koje su izazvale nezadovoljstvo sovjetskih predstavnika u FNRJ bila je knjiga Uvod u sociologiju čuvenoga pravnika, profesora Radomira Lukića s Univerziteta u Beogradu, tretirana kao „oličenje buržoaskih shvaćanja”. S negodovanjem je tretiran i nastup ravnatelja Instituta za međunarodna pitanja Janeza Stanovnika, koji je osuđivao sovjetski nastup prema zemljama istočnoga bloka. Zamjeralo se i zbog knjige Stevana Belića-Franića Drugi svetski rat i radničke partije. Belić-Franić iznio je mišljenje da je suradnjom sa zapadnim zemljama, a ponajviše zbog držanja SSSR-a u Kominterni, Staljin spriječio mogućnost oblikovanja šire fronte antifašizma. $\mathrm{Na}$ osnovi navedenog vidi se da su neki od istaknutih jugoslavenskih autora iskorištavali povijesne činjenice za podcjenjivanje sovjetskih postupaka na međunarodnom planu. Belić-Franić naglasio je naime agresivnu politiku Moskve prema Srednjoj Europi, oličenu u podjeli ovoga dijela Staroga kontinenta paktom Ribbentrop-Molotov od 23. kolovoza 1939. godine. Zamčevskij je također negativnom ocijenio činjenicu da je spomenuti politolog kritizirao politiku Moskve prema Jugoslaviji u ratnim godinama i slabo naglasio sovjetski udio u pobjedi nad nacističkom

16 RU-РГАНИ, ф. 5, оп. 49, д. 39, Б. Брыкин, Советникпосольства СССР в СФРЮ, О подготовке в Югославии к празднованию 40-ц̆ годовщиньоктябьрскойреволющии, 21 октябра 1957 г., 323.

17 RU-РГАНИ, ф. 5, оп. 49, д. 39, Б. Брыкин, Советникпосольства СССР в СФРЮ, О подготовке в Югославии к празднованию 40-ц̆ годовщиньоктябьрскойреволющии, 21 октябра 1957 г., 323-324. 
Njemačkom, govoreći i o suradnji Moskve s Londonom. ${ }^{18}$

Primjedbe Sovjeta u vezi s jugoslavenskom megalomanijom potencirala je američka kulturna politika prema Srednjoj Europi. Kulturnom prisutnosti, smatrali su predstavnici Kremlja u Beogradu, vršen je „ideološki prodor”. Radina Vučetić navodi da su već 50-ih godina izložbe bile sredstvo Sjedinjenih Američkih Država (SAD) za pridobivanje prestiža. Na razne se načine predstavljalo nacionalne brendove i pokušavao pridobiti entuzijazam i izvan zapadnoga svijeta, o čemu svjedoči izložba SAD-a u Moskvi 1959. godine. ${ }^{19}$ Kao što je navedeno u sovjetskoj dokumentaciji iz kolovoza 1957., američki kulturni centri u Beogradu, Zagrebu, Novom Sadu i Sarajevu raspolagali su znatnim sredstvima radi promidžbe zapadnih političkih i kulturnih uzora. Prikazivanjem filmova, glazbom, otvaranjem knjižnica i nastavom engleskoga jezika Amerikanci su neusporedivo uspješnije naspram Sovjeta, priznavao je prvi tajnik veleposlanstva Dmitrij Sevjan, predstavljali društvu zapadne vrijednosti. Zagrebački centar bio je najjači iza beogradskoga. U prijestolnici Jugoslavije od 26. siječnja do 24. veljače 1957. organizirana je, primijećeno je u dokumentaciji, velika izložba čiji je sadržaj trebao uvjeriti društvo u univerzalizam američkih ideja. Washington je uspjesima u medicini, tehnici ili širem znanstvenom životu afirmirao superiornost vlastitoga društvenog, ekonomskog i političkog uređenja. Sovjetski su diplomati primijetili da je sva sofisticiranost američke propagande bila u odsutnosti političkoga sadržaja, iako se na ulazu nalazila velika slika predsjednika Dwighta Eisenhowera. Radi blagonaklonoga stajališta SAD-a prema Jugoslaviji u biltenu koji je izdavalo veleposlanstvo SAD-a objavljeno je u proljeće 1957. priopćenje senatora Davida Kleina, koji je uvjeravao Kongres da je potrebna daljnja podrška SAD-a nezavisnosti Jugoslavije. Sovjeti su skrenuli pozornost na to da je jugoslavenski tisak zaobišao sadržaj spomenutoga govora i da je najveći uspjeh zapadnoga utjecaja bio primjetan u NR Hrvatskoj s obzirom na, po mišljenju predstavnika Kremlja u Jugoslaviji, najveću razinu „reakcionarnih raspoloženja društva” upravo na teritoriju Hrvatske. Može se zaključiti da je privlačnost zapadnih utjecaja, njihova šarolikost, najviše plašila Sovjete po pitanju plasiranja vlastitih proizvoda u Jugoslaviji i širom svijeta. Uski, ideološki ograničeni horizonti Moskve stvarali su strah i u mnogočemu apsurdna uvjerenja o tobožnjem tajnom utjecaju Katoličke crkve kao vjerske zajednice, čiji su univerzalni pogledi sa sumnjičavošću promatrani kao „ideološki imperijalizam”. Na taj je način tajnik sovjetskoga veleposlanstva Sevjan govorio o zapadnim utjecajima u Hrvatskoj preko Katoličke crkve i upravo nju okrivljavao za slabost sovjetske propagande u Zagrebu i drugim gradovima Hrvatske. ${ }^{20}$ Ustvari je ponavljao za komuniste tipične tvrdnje poput one koju je na zasjedanju Saveznoga izvrš-

18 RU-РГАНИ, ф. 5, оп. 49, д. 39, И. Замчевскийпосольство СССР в СФРЮ в секретариаттоварища Д. Т. Шепилова, Деятельност СКЮ в области идеологической работьы, 22 мая 1957 г., 261-264.

19 VUČETIĆ, Koka-kola socijalizam, 356-357.

20 RU-РГАНИ, ф. 5, оп. 49, д. 39, Д. Севьян, І секретар посольства СССР в ФНРЮ, Об американской пропаганде в Югославии, 21 Ш 1957 г., 267-270, 273. 
nog vijeća izgovorio Ivan Krajačić: „Kada se govori o Rimokatoličkoj Crkvi nitko nije više internacionalan nego ovi gadovi iz redova Rimokatoličke Crkve", čime se neizravno referirao na popularnost i društveni položaj te vjerske zajednice kao konkurenciju komunističkome monopolu. ${ }^{21}$

Ideološka problematika u vidu obrane od istočnoeuropskih utjecaja zapažena je i u pogledu zaključaka nakon VII. kongresa SK Jugoslavije 1958. godine. Uoči priprema kongresa znatno su poremećeni odnosi Jugoslavije i istočnoga bloka. Jugoslavenski komunisti isticali su da je njihov program bio prvi koji je doista odlučno osudio staljinizam i isticao značaj komunizma kao univerzalnoga procesa ne nametanjem jedinstvenih uzora nego kroz „reafirmaciju idejno-teorijskih shvaćanja”. 22 Sovjeti zainteresirani za odjeke u Jugoslaviji primijetili su da su republičke i pokrajinske organizacije dugo iščekivale razmatranje zaključaka donesenih na ljubljanskom kongresu. $\mathrm{Na}$ osnovi članka iz svibnja 1958. objavljenog u Komunistu navođeno je da je Partija počinila greške u vezi s objašnjavanjem smisla zaključaka kongresa, a partijska organizacija u Zagrebu nije ni počela s kolportažom materijala, kao ni s propagandnim radom među omladinom. Pozivajući se na izvore u Centralnom komitetu SK Hrvatske, navodilo se da su hrvatski komunisti očekivali dopunske materijale Centralnoga komiteta SK Jugoslavije te nisu žurili s propagandom i provođenjem zaključaka. Drugi tajnik veleposlanstva B. F. Suhomlinov, oslanjajući se na tisak, s omalovažavanjem je tretirao ideološki rad Partije u društvu, govoreći da je smjer SK Jugoslavije „antilenjinistički i revizionistički”. Osobito se negativno izražavao o zaključcima s partijskoga plenuma Centralnoga komiteta SK Vojvodine, gdje je po mišljenju Sovjeta rasprava o poljoprivredi bila svedena na podršku bogaćenju seljaka, tj. „kulaka”. Iako se smatralo da je društvo bilo nezainteresirano za smjernice, o čemu je svjedočila navodna gomila netaknutih materijala na kioscima, diplomati akreditirani u FNRJ vidjeli su pojačanu aktivnost političara. Najveća budnost zapažena je u vojsci. Naveden je članak generala Ivana Krajačića u časopisu Narodna armija od 28. svibnja 1958., čiji je sadržaj, smatralo se u Moskvi, trebao stvoriti dojam da je vojska spremna po svaku cijenu braniti jugoslavensku nezavisnost. Propagandna mašinerija bila je usmjerena i prema omladini, vođena od predsjednika CK SK Hrvatske Vladimira Bakarića te predsjednika Saveza omladine SK Hrvatske. Na općejugoslavenskom plenumu omladine riječ je uzeo predsjednik te organizacije Miko Tripalo, koji je krajem svibnja 1958. govorio o novom programu SK Jugoslavije i pripremama za 40. godišnjicu osnivanja Partije 1959. godine. ${ }^{23}$

Početkom 60-ih godina Sovjeti su primijetili da su se Slovenci i Hrvati najjače zalagali za promjene u okviru Komisije za izradu novoga Ustava. Diplomat Jegorihin izvještavao je u vezi s Titovim govorom iz Splita 5. svibnja

21 AKMADŽA, Katolička crkva u komunističkoj Hrvatskoj, 180.

22 PLETERSKI et al., Povijest Saveza komunista Jugoslavije, 405-406.

23 RU-РГАНИ, ф. 5, оп. 49, д. 121, Б. Ф. Сухомлинов, Политико-массовая работа СКЮ после УП сьезда СКЮ. Информация, 16 юня 1958, 135-144. 
1962., u kojem je jugoslavenski vođa osudio zatvaranje republičkih tržišta. Pojavili su se zahtjevi za smjenjivanje prvoga sekretara Partije u Hrvatskoj Vladimira Bakarića, kao i u Srbiji Jovana Veselinova, koji navodno nisu bili uspješni u suzbijanju nacionalizma. ${ }^{24}$

U smjernicama sovjetske politike prema Jugoslaviji Jegorihin nije baš bio originalan. Tražio je od nadležnih u Ministarstvu vanjskih poslova SSSR-a da se „isticanjem vodeće uloge Partije i Lenjinovih principa nacionalne politike" Jugoslavenima pokaže uzor učinkovitoga rješavanja nacionalnoga pitanja. Preko kontakata među sovjetskim i jugoslavenskim republikama, pri čemu je Hrvatskoj namijenjena suradnja s Ukrajinom, u diplomatskim krugovima SSSR-a vjerovalo se u mogućnost utjecaja na Jugoslaviju. Na osnovi spomenutoga dokumenta stječe se dojam da je mišljenje Kremlja bilo da je upravo odstupanje Beograda od sovjetskih uzora dovodilo do pojave brojnih problema, među ostalim na nacionalnoj razini. ${ }^{25}$

U sklopu poboljšanja odnosa Jugoslavije i istočnoga bloka 60 -ih godina te posjeta sovjetskoga državnog vrha Beogradu, smatralo se da bi delegacija predvođena Leonidom Brežnjevom i Aleksejem Kosiginom mogla povoljno utjecati na približavanje SFRJ istočnom bloku te radi sovjetskih interesa u Trećem svijetu preko Pokreta nesvrstanih stvoriti uvjete za zajednički nastup Moskve i Beograda. ${ }^{26}$ Prilike u Hrvatskoj promatrale su se u vezi s provođenjem zaključaka VIII. kongresa SK Jugoslavije iz 1964., kojima se težilo afirmaciji unutarnjih i vanjskih političkih principa zemlje. Peti kongres u Hrvatskoj 26. - 29. travnja 1965. izazvao je pozornost s obzirom na to da je s referatom zbog bolesti Bakarića nastupio Aleksandar Ranković. Sovjeti su primijetili da su se u centru pozornosti našli „uloga SK Jugoslavije kao vodeće snage” u Jugoslaviji, „razvoj samoupravljanja”, kao i ideološki utjecaj Partije u društvenom životu. Primijećeno je da je upravo u NR Hrvatskoj nastalo najviše komisija, poput onih za ideologiju, omladinu i kadrovska pitanja. Iako su zaključci bili poprilično enigmatski - jer pred javnošću nitko nije bio okrivljen za probleme u samoupravljanju, gospodarstvu te za nisku razinu ideološkoga utjecaja - diplomati su primijetili velike promjene u strukturama Partije, gdje je u Centralni komitet stupilo oko 50\% potpuno novoga kadra, dok je Izvršni komitet ostao uglavnom neizmijenjen. ${ }^{27}$

24 RU-РГАНИ, ф. 5, оп. 49, д. 516, І секретар посольства СССР в ФНРЮ М. Егорихин, Национальные взаимоотночения в современной Югославии. Справка, 26 августа 1962 г., 175-177.

25 Isto, 178.

26 RU-РГАНИ, ф. 5, оп. 49, д. 809, Пузанов, посольство СССР в СФРЮ, Предложения посольства СССР в СФРЮ по дальнейшему развитию советско-югославских отночений, 24 сентября 1965, 126.

27 RU-РГАНИ, ф. 5, оп. 49, д. 809, А. Кузьмин, Первый секретар Посольства СССР в СФРЮ, Об итогах съездов Союза Коммунистов Республик-информация, 10 юня 1965, 3945. 


\section{Nacionalno pitanje i opća društvena situacija}

U pogledu društvenih pitanja najzanimljivije za Sovjete bilo je ono nacionalno. Po njihovu mišljenju, vlasti Jugoslavije nakon 1945. poduzele su pravilne korake za rješavanje nacionalnoga pitanja. Na taj način period nakon 1945. suprotstavljen je u sovjetskoj vizuri Kraljevini Jugoslaviji, a to se mišljenje dominantno odnosilo upravo na Hrvatsku. U vezi s uvođenjem diktature kralja Aleksandra 1929., u sovjetskoj dokumentaciji iz 60-ih navodile su se činjenice o ukidanju povijesne autonomije Hrvatske, Dalmacije i Krajine obojene ideološkim shvaćanjem o „strahu srpske buržoazije koja je težila samovlasti, lišavanju legalnih prava ne samo seljaka i radnika nego i interesa nesrpske buržoazije". Netočnost navođenih podataka svjedoči o ograničenoj povijesnoj spoznaji diplomata poslanih iz Moskve u Jugoslaviju. Treba imati na umu da sve do 1929. Krajina nije imala nikakvu autonomiju. Kroz ideološku paradigmu, Sovjeti su smatrali da su potezi Karađorđevića bili izazvani u prvom redu strahom od revolucije. Brzi prodor Hitlera i osvajanje Jugoslavije 1941. tretiralo se kao izraz neriješenoga nacionalnog pitanja. Takvo tumačenje tipično je za sovjetski pogled na Srednju Europu, čiji su režimi iz međuratnoga razdoblja tretirani kao neprijateljski te vrlo često i lažno potpuno obezvređivani primjerice pripisivanjem kolaboracije i pasivnoga stajališta prema okupatorima. Jedino su stranke spremne prihvatiti sovjetsku dominaciju i suradnju s komunistima smatrane „antifašističkima”, zaobilazeći mnoge nijanse. U tom duhu, sovjetski diplomati tvrdili su da su na ovaj ili onaj način sve predratne stranke, poput srpske Demokratske stranke i Hrvatske seljačke stranke, ušle u kolaboraciju. S druge strane smatralo se da su komunisti pomoću revolucije, „bratstva i jedinstva”, uspjeli riješiti napetosti i konflikte između Srba i Hrvata, pravoslavaca i katolika, kao i muslimana. ${ }^{28}$

Nacionalnu politiku Jegorihin je podijelio na dva perioda: prvi je nastupio odmah nakon rata, uspostavljanjem državnosti i donošenjem Ustava 1946., „ujedinjavanjem ravnopravnih naroda”, kad se odluka republičkih vlasti smatrala izrazom „volje nacija”. Početak drugoga perioda vezan je uz sovjetsko-jugoslavenski konflikt 1948., uz nastupanje „nacionalističkih stavova”, a završio je uvođenjem samoupravljanja 1952. godine. Taj su period Sovjeti gledali s negodovanjem, kao isticanje „revizionizma” u pogledu izgradnje političkoga sustava i upravljanja gospodarstvom. Samoupravljanje se držalo težnjom za pomirenjem razlika u gospodarskom razvoju te kulturnih raznolikosti pojedinih regija Jugoslavije i rješavanjem nacionalnih problema. ${ }^{29}$ Ustvari su Sovjeti isticali unutarnje probleme zemlje zbog nezadovoljstva politikom Josipa Broza Tita, koja je bila neovisna o Moskvi, i nepriznavanja sovjetske superiornosti. Zanemarena je činjenica koju je istaknuo Zdenko Radelić, da su ju-

28 RU-РГАНИ, ф. 5, оп. 49, д. 516, I секретарпосольства СССР в ФНРЮ М. Егорихин, Национальные взаимоотночения в современной Югославии. Справка, 26 августа 1962 г., 158-161.

29 Isto, 161, 164-165, 167. 
goslavenski komunisti, osim traženja vlastitoga puta i dokazivanja ispravnosti u sukobu sa Sovjetima optuživanim za „birokratski hegemonizam”, težili uz zadržavanje kontrole u političkoj i gospodarskoj sferi preko samoupravljanja građanima dati privid demokracije. ${ }^{30}$

U izvještaju prvoga tajnika veleposlanstva u Beogradu Jegorihina iz kolovoza 1962. u vezi s raspravama o novom ustavu, povećanju samoupravljanja i uspostavi fonda federacije za kreditiranje bržega razvoja privredno nedovoljno razvijenih republika i pokrajine Kosovo, navodilo se da su gospodarski egoizmi republika iskazivani u rastućem nacionalizmu. Smatralo se da su „ugrožene tekovine revolucije”, pa su navođeni Titovi govori objavljeni u Borbi 6. i 7. svibnja kao i 25. srpnja 1962., u kojima je jugoslavenski vođa osuđivao „pasivnost” komunista, a kulturne radnike optuživao za „buržoaska izopačenja”. Tito se na IV. plenumu SK Jugoslavije 1962. osvrnuo na nacionalno pitanje, govoreći da je riješeno u vrijeme rata i nakon njega te da je vraćanje toj temi 60 -ih godina nepotrebno i egocentrično. ${ }^{31}$

U vezi sa spomenutim raspravama o razini decentralizacije i samostalnosti republika u Moskvi je primijećeno da je politika komunista uspješno podigla životni standard te uklonila nepismenost u siromašnijim republikama poput Makedonije, Bosne i Hercegovine i Crne Gore. S druge strane promjene u političko-gospodarskom sustavu doprinijele su po mišljenju Sovjeta još većoj uočljivosti nacionalnoga pitanja. Jegorihin je naime izvještavao da je rastuća samostalnost republika pridonosila učvršćivanju nacionalizma i šovinizma kroz egoističke pristupe ne samo republika nego i lokalnih zajednica. Veća samostalnost poduzeća pokazala je, uvjeravao je Jegorihin, da su ona najefikasnija ponajviše smještena u Sloveniji, Hrvatskoj i dijelom u Srbiji. Upravo su ta poduzeća raspolagala boljim inženjerskim kadrom, tehničkom opremom i izdvajala veće plaće za zaposlene. Hrvatska je s pravom spomenuta kao druga najbogatija republika zbog visokoga sudjelovanja u jugoslavenskom bruto proizvodu i poljoprivredi. Sovjetski predstavnici navodili su u dokumentima da je sa 600 tvornica na vlastitom teritoriju NR Hrvatska imala 150\% više tvornica od Makedonije, Bosne i Hercegovine i Crne Gore ukupno. Rast nacionalizma u bogatijim republikama Sovjeti su vezali uz njihov otežani ulazak na tržišta siromašnijih. ${ }^{32}$

Nacionalno pitanje i neravnomjeran razvoj bili su i tema razgovora docenta slavistike sa Sveučilišta u Zagrebu Malika Mulića sa I. K. Kiseljevim tijekom posjeta znanstvenika Taškentu u Uzbekistanu. Sovjetski diplomat raspitivao se za trenutačno društveno stanje u pogledu međunacionalnih odnosa, pozivajući se na tekstove Tita i Bakarića i polemiku između pobornika i protivnika decentralizacije i veće samostalnosti republika. Slavist je uvjeravao da se

30 RADELIĆ, Hrvatska u Jugoslaviji, 287-288.

31 RU-РГАНИ, ф. 5, оп. 49, д. 516, I секретар посольства СССР в ФНРЮ М. Егорихин, Наииональные взаимоотночения в современной Югославии. Справка, 26 августа 1962 г., 152-154.

32 Isto, $168-174$. 
ustvari radi o gospodarskim problemima koji nemaju veze s nacionalnim pitanjima, a osjećaj nepravde i tobožnjega gubitka bio je rasprostranjen u svakoj republici zbog obveza izdvajanja sredstava za federalne fondove. Napomenuo je također da je cijela priča vezana uz radikalne promjene izazvane reformom iz 1965., koja je, gledano u cjelini, drastično snizila životni standard. ${ }^{33}$

U vezi s nacionalnim problemima koji su se odražavali i na gospodarskom planu Sovjeti su kao negativne čimbenike navodili utjecaj emigracije i Katoličke crkve. Na osnovi jugoslavenskoga dnevnog tiska tvrdilo se da je odljev malobrojne stručne radne snage izazivao zabrinutost te se upućivalo na raspravu iz studenoga 1965. na sjednici Centralnoga vijeća Saveza sindikata o tom problemu. Sovjeti su smatrali da su političari u Jugoslaviji jedno vrijeme umanjivali utjecaj odlazaka u inozemstvo te navodili sadržaj teksta iz Politike u kojem je bilo riječi o negativnom utjecaju političke emigracije na privremene radnike. ${ }^{34}$

Vezano uz nacionalno pitanje, sovjetski su izaslanici iz ideoloških razloga osuđivali djelovanje Katoličke crkve kao predstavništva Vatikana, tobože usredotočeno na „širenje mržnje i nesnošljivosti” prema ostalim vjerskim i nacionalnim zajednicama. ${ }^{35}$ Kao što je tvrdio profesor Malik Mulić tijekom posjeta SSSR-u 1965., upravo je Crkva bila „uporište neprijatelja režima” ${ }^{36} \mathrm{Di}$ plomat u Jugoslaviji Dmitrij Sevjan navodio je 1957. da je Crkva u Hrvatskoj uspijevala stvoriti „uporište za širenje američke propagande” u toj republici. Kao „dokaz” Sovjeti su tretirali činjenicu da su katolički krugovi posredovali u američkoj pomoći djeci u Jugoslaviji akcijom besplatnih doručaka pokrenutom u rujnu 1956. godine. S negodovanjem je Sevjan tvrdio da je akcijom, široko opisivanoj u biltenu američkoga veleposlanstva, obuhvaćeno dvije trećine djece u zemlji. ${ }^{37}$ Zapravo su Sovjeti ignorirali poboljšanje odnosa Katoličke crkve i države krajem 50-ih. Koristili su paušalne ocjene ideološkoga karaktera poput one koju je izrekao predsjednik Savezne komisije za vjerska pitanja Dobrivoje Radosavljević u listopadu 1959., kad je prigovorio nadbiskupu Josipu Ujčiću da se vjersko djelovanje svećenika „[...] često ispoljava u izazivanju nacionalne i verske netrpeljivosti, mržnje ili razdora" ${ }^{38}$ Sovjeti nisu obraćali pozornost na promjene odnosa Vatikana i Jugoslavije, uočljive

33 RU-РГАНИ, ф. 5, оп. 49, д. 875, И. К. Кисиелев, Запись беседы с профессором кафедрь славянских языков Загребского университета М. Муличем, 28 января 1966 г., 36.

34 RU-РГАНИ, ф. 5, оп. 49, д. 875, Н. Лыков, Ш секретар посольства СССР в СФРЮ, О выезде югославских рабочих и специалистов на работу загранииу (Информация), 11 март 1966 г., 74-80.

35 RU-РГАНИ, ф. 5, оп. 49, д. 516, І секретарпосольства СССР в ФНРЮ М. Егорихин, Национальные взаимоотношения в современной Югославии. Справка, 26 августа 1962 г., 157.

36 RU-РГАНИ, ф. 5, оп. 49, д. 809, И. К. Киселев, Запись беседь с профессором кафедрь русского языка Загребского университета М. Муличем, 23 мая 1965 г.

37 RU-РГАНИ, ф. 5, оп. 49, д. 39, Д. Севьян, І секретар посольства СССР в ФНРЮ, Об американской пропаганде в Югославии, 21 Ш 1957 г., 270, 273.

38 AKMADŽA, Katolička crkva u komunističkoj Hrvatskoj, 183. 
sredinom 60-ih godina, o kojima svjedoči razgovor pape Pavla VI. s jugoslavenskim diplomatom Ivo Vejvodom početkom 1965., kad ga je poglavar Svete Stolice uvjeravao da se usprkos zalaganju za vjerske slobode Vatikan nije kanio miješati u jugoslavensku unutarnju politiku. ${ }^{39}$

Na društvenom planu negodovanje u Moskvi izazivalo je i pisanje novina, prije svega zagrebačkoga Vjesnika. Jedan od načina pokazivanja odbojnosti prema najpopularnijim novinama u Hrvatskoj bilo je odbijanje sovjetskih diplomata molbe koju je uredništvo predvođeno Josipom Vrhovcem uputilo Hruščovu u vezi sa sovjetskim prijedlozima miroljubive politike. Veleposlanik Deduškin s omalovažavanjem je opisivao Vjesnik u srijedu kao „senzacionalistički dnevnik", zainteresiran za zapadni život, u kojem događaji iz istočnoga bloka praktički nisu bili zastupljeni. Drsko je predložio sekretaru Centralnoga komiteta KPSS-a odgovornom za veze s komunističkim partijama u inozemstvu Juriju Andropovu da se u odgovoru navede da je prvi sekretar KPSS-a zauzet, pa neka uredništvo potraži odgovor u javnim nastupima sovjetskoga vođe. Taj je prijedlog odobrio Andropovljev zamjenik Boris Mirošničenko, koji se složio s navodima Deduškina. ${ }^{40}$

\section{Gospodarstvo}

Gospodarsko stanje u Jugoslaviji bilo je od velike važnosti za Sovjete zbog općih interesa suradnje s Jugoslavijom. U osvrtu na unutarnje prilike gospodarsko je pitanje u Kremlju čvrsto vezano i uz nacionalno. U SSSR-u je primijećena činjenica koja je u Jugoslaviji prvi put priznata 60-ih godina, da postoje izvjesne razlike u razvoju pojedinih dijelova države. ${ }^{41} \mathrm{U}$ Moskvi se naime smatralo da komunisti na Balkanu nisu uspjeli savladati duboki razdor između siromašnijega juga i bogatijega sjevera zemlje. Prvi tajnik sovjetskoga veleposlanstva u Beogradu Jegorihin navodio je 1962. da su se Slovenija i Hrvatska tijekom povijesti istaknule kao najrazvijeniji dijelovi Jugoslavije, nakon 1918. njihovu se razvoju donekle približila Srbija, a ostali dijelovi zapadnoga Balkana, usprkos naporima komunista, izrazito su zaostajali za tim republikama. ${ }^{42}$ Pozivajući se na Privredni pregled od 10. kolovoza 1962., zaključeno je da je Slovenija u petogodišnjem razdoblju od 1954. zabilježila dvostruki rast bruto domaćega proizvoda, a boljitak u Makedoniji bio je izrazito manji. ${ }^{43}$

Sovjeti su još sredinom 50-ih godina bili zainteresirani za upoznavanje jugoslavenskoga gospodarstva u sklopu općih težnji za modernizacijom vlasti-

39 Isto, 296-298.

40 RU-РГАНИ, ф. 5, оп. 49, д. 39, П. Дедушкин до Ю. А. Андропова, 25 декабря 1957 г., 353-354.

41 RADELIĆ, Hrvatska u Jugoslaviji, 335.

42 RU-РГАНИ, ф. 5, оп. 49, д. 516, И секретар посольства СССР в ФНРЮ М. Егорихин, Национальные взаимоотношения в современной Югославии. Справка, 26 августа 1962 г., 157.

43 Isto, 171-173. 
toga gospodarstva. U skladu s dokumentom od 26. listopada 1955. O sredivanju putovanja sovjetskih specijalista u inozemstvo radi izučavanja postignuća stranoga znanja i tehnike i o poboljšanju korištenja materijala s tih putovanja od strane ministarstava i odjeljenja SSSR-a, veleposlanik Jegorihin je skrenuo pozornost na Zagrebački velesajam kao izrazito važan događaj. Gospodarska izložba u Zagrebu mogla bi služiti, kako stoji u dokumentu, kao pouzdan izvor saznanja o dostignućima jugoslavenske privrede, osobito industrije. U vezi sa samom Hrvatskom, Jegorihin je tvrdio da je dotad zanemaren aspekt suradnje u oblasti prehrambene industrije otvarao moguće koristi za SSSR. S druge strane veleposlanik se negativno izražavao o slanju sovjetskih stručnjaka u tvornicu „Rade Končar”, ocjenjujući da je razina proizvodne moći bila prilično niska, stoga koristi od izučavanja tamošnjega djelovanja nisu bile važne za Moskvu. ${ }^{44}$

Još sredinom 50-ih godina veleposlanik se s omalovažavanjem izražavao o općoj kulturi rada u Jugoslaviji te besmislenim smatrao slanje stručnjaka za izučavanje poslovanja brodogradilišta, navodeći kao po njegovu mišljenju neproduktivan posjet sovjetskih stručnjaka Rijeci 1956. godine. ${ }^{45}$ Situacija se očito promijenila deset godina poslije, kad je tajnik sovjetskoga veleposlanstva P. D. Minjejev priopćavao da su od 1965. hrvatska brodogradilišta „3. maj”, „Uljanik” i „Split” počela proizvoditi brodove poput tankera i teretnjaka za isporuku Sovjetskom Savezu i na osnovi razgovora sa sovjetskim inženjerima pridošlim u Split govorio o visokoj radnoj kulturi. Te 1965. SSSR je preuzeo 12 brodova ukupnoga kapaciteta 205,6 tona. Minjejev je tvrdio da je 60-65\% proizvodnje hrvatskih brodogradilišta bilo za isporuku Sovjetima. Važan dio suradnje trebala je činiti i obnova sovjetskih brodova. Direktor brodogradilišta u Splitu sa zadovoljstvom je govorio o suradnji sa sovjetskim stručnjacima koji su došli u Split. Dodao je da su jugoslavenski inženjeri stjecali iskustvo prije svega na Zapadu, a i iskustvo boravka u SSSR-u moglo bi se pokazati korisnim. ${ }^{46}$

Šezdesetih godina, s porastom ukupne gospodarske suradnje sa SSSR-om, sovjetski diplomati u Jugoslaviji imali su sve više prijedloga vezanih uz korištenje ne samo jugoslavenskoga tržišta nego i kontakata te zemlje s nesvrstanima. Veleposlanik Puzanov tvrdio je da bi Zagrebački velesajam bio iznimno koristan radi promidžbe sovjetskih proizvoda pred izlagačima iz zemalja u razvoju, prije svega vezano uz gotove tvornice i kombinate. Gospodarski kontakti bili su u nekoj mjeri ocjenjivani kao korisni zbog gospodarske prisutnosti Zapada u SFRJ te mogućnosti dobivanja novih tehnologija. Samo deset godina prije omalovažavani, „Rade Končar” i Institut za geološka istraživanja u Zagrebu smatrani su pogodnim mjestima za izučavanje zapadne proizvod-

44 RU-РГАНИ, ф. 5, оп. 49, д. 39, Н. Фирюбин, посоль СССР в СФРЮ заведующему 5-м еврпейским отделом МИД СССР, 5 апреля 1957 г., 65.

45 Isto, 65-66.

46 RU-РГАНИ, ф. 5, оп. 49, д. 875, П. Д. Минеев, Информация о посещценийи югославских судостроительных предпиятей в городах Риека, Пула и Сплит, 15 января 1966 г., 24-26. 
nje. Zbog toga je Puzanov predlagao povezivanje brodogradilišta u Odesi, Lenjingradu i Hersonu s onima u Rijeci, Splitu i Puli. Izjavljivao je također da bi Hrvatska bila pogodna za izučavanje kemijske industrije u sklopu znanstveno-tehničke suradnje dviju zemalja. ${ }^{47}$

Sovjeti su pridavali veliku važnost Zagrebačkom velesajmu, najvećem u Jugoslaviji. U sklopu njihove politike, prisutnost na svjetskim manifestacijama poput Zagrebačkoga velesajma bila je važna za vanjsku propagandu, kako gospodarsku tako i političku. ${ }^{48}$ Vrijedi napomenuti da su posjetitelji uglavnom dolazili radi upoznavanja tehničkih postignuća Zapada. Izlagana su ne samo tehnička dostignuća nego i proizvodi svakodnevne potrošnje poput stroja za točenje Coca-Cole ili aparata za cigarete. Dok su Amerikanci uglavnom predstavljali „blago” potrošačkoga društva, Sovjeti su bili usredotočeni na prikazivanje svojih tehničkih dostignuća poput rudarskih strojeva, maketa hidroelektrana i sl. Kako je slikovito zaključila Radina Vučetić, sovjetska poruka s izložbe bila je da uz pomoć strojeva čovjek može služiti državi, a Amerikanci su nastojali pokazati da država uz pomoć tehničkih dostignuća može služiti čovjeku. ${ }^{49}$

\section{Kultura}

Sovjetsko negodovanje zbog mnogih pojava na političkom planu u Jugoslaviji imalo je odraz i u sumnji u pogledu kulturnih prilika u toj državi. U dokumentu Bilješka o antisovjetskim i antisocijalističkim materijalima objavljivanim u jugoslavenskom tisku navedeni su podaci sovjetske cenzure (Glavlit) o zapljenjivanju u drugom polugodištu 1957. čak 88 jugoslavenskih časopisa. Zamijećeno je da su se u tim glasilima nalazili članci pretiskani iz zapadnih novina u kojima se navodno izrugivalo sovjetskom režimu. Među zabranjenim primjercima nalazili su se pojedini brojevi beogradskih Politike i Ježa, skopske Nove Makedonije, novosadskoga Dnevnika, zagrebačkoga Vjesnika, a ponajviše slovenskih časopisa poput Nove revije, Tovariša, Kmečkoga glasa, Slovenskoga poročevalca, Naših razgleda ili satiričkoga časopisa Pavliha. Zaplijenjeno je i izdanje Borbe (zagrebačko i beogradsko) od 22. kolovoza 1957. zbog „klevetničkih navoda” njujorškoga dopisnika o razotkrivanju u Americi sovjetskoga špijuna „Abela”. Najveće je negodovanje izazivalo ipak pisanje jugoslavenskih glasila o promjenama u Sovjetskom Savezu - destaljinizaciji nakon XX. kongresa KPSS-a, događajima u Poljskoj u lipnju 1956., kao i krvavom gušenju Mađarske revolucije u studenome 1956. godine. Slovenski Naši razgledi u brojevima od 14. srpnja i 26. listopada 1957. objavili su članak „Ka

47 RU-РГАНИ, ф. 5, оп. 49, д. 809, Пузанов, посольство СССР в СФРЮ, Предложения посольства СССР в СФРЮ подальнейшему развитию советско-югославских отночений, 24 сентября 1965, 130-131, 135.

48 НАГОРНАЯ, „Витрыны споветских достижений’: СССР на международных выставках товаров народного потребления”, 86-95.

49 VUČETIĆ, Koka-kola socijalizam, 359-365. 
poljskim događajima u Moskvi”, u kojem se s odobravanjem gledalo na osudu Staljina i udaljavanje od staljinističkih principa, kao i na djelomičnu rehabilitaciju žrtava staljinizma. U tekstu je ipak osuđeno sovjetsko gušenje ustanka u Mađarskoj ujesen 1956. kao izraz agresije. ${ }^{50}$

Sovjetsku pozornost privukle su dvije knjige čiji su istaknuti autori Dobrica Ćosić i Predrag Vranicki osuđivali sovjetsku politiku. U knjizi 7 dana $u$ Budimpešti srpski se pisac sa simpatijom odnosio prema narodima nastanjenim u SSSR-u, no pobunu u Mađarskoj tretirao je kao težnju naroda Srednje i Istočne Europe za oslobođenjem od staljinizma, a osude Staljina i Rákosija kao izraz potrage za izgradnjom „pravoga socijalizma”. Knjiga Filozofske studije i kritika Predraga Vranickog s druge strane kritizirana je u Moskvi, a čuvenom filozofu zamjerila se osuda sustava i vlasti koja je, vršeći pritisak na društvo, pripisivala sebi pravo da definira slobodu. Vranicki je naime navodio, prema riječima sovjetskih diplomata, da su usprkos parolama o slobodi vlasti SSSR-a lišavale pojedinca svakoga vida subjektiviteta. S velikim negodovanjem tretiran je u Zagrebu 1956. objavljen udžbenik Tome Čubelića Povijest za 8. razred narodne osmogodišnje škole, u kojem je autor pripisivao Sovjetima da su bili protiv industrijalizacije i elektrifikacije Jugoslavije jer su nakon 1945. namjeravali eksploatirati njezino gospodarstvo, oslonjeno isključivo na poljoprivredu. Čubelić je, kaže se u sovjetskom dokumentu, osuđivao i Kremlj da je, pozivajući narode Jugoslavije na ustanak protiv Komunističke partije Jugoslavije 1948., radio na upropaštavanju „tekovina revolucije”. ${ }^{51}$

Pitanje kulturnoga života u Hrvatskoj i cijeloj Jugoslaviji koje je izazivalo najveću pozornost, a i uzrujanost Sovjeta, bio je navodni jak utjecaj Zapada. Kultura je bila jedno od važnijih područja nadmetanja supersila u vrijeme hladnoga rata. Nije slučajnost da je administracija predsjednika Dwighta Eisenhowera upravo na tom području pokušavala zadobiti naklonost društava u zemljama Srednje Europe. Kako je zaključio poljski povjesničar Jakub Tyszkiewicz, direktiva Nacionalnoga vijeća za sigurnost (National Security Council) 5607 iz lipnja 1956. označavala je postupno odbacivanje „psihološkoga rata" na račun kulturnih i znanstvenih kontakata, pomoću kojih bi vjerovalo se u Washingtonu - komunističke vlasti u Srednjoj Europi bile prisiljene na liberalizaciju društvenoga života. Tome su služili programi kulturne razmjene, davanje stipendija znanstvenicima i sl. ${ }^{52}$

Još 1958. čehoslovački konzul u hrvatskoj metropoli uvjeravao je drugoga tajnika sovjetskoga veleposlanstva u Beogradu o „velikom prodoru” zapadne kulture u toj republici. Od u Zagrebu postojećih informativnih i kulturnih centara SAD-a, Velike Britanije, Francuske, Austrije i Italije upravo su dje-

50 RU-РГАНИ, ф. 5, оп. 49, д. 123, П. Романов, Началник Главного управления по охране военных и государственных тайн в печати при Совете Министров СССР, 14 января 1958 г., Справка об антиосоветских и антисоииалистических материалах, опубликованных в югославской печати, 13.

51 Isto, 13-14.

52 TYSZKIEWICZ, Rozbijanie monolitu, 168-169. 
latnici poslani iz Washingtona vodili najaktivniju kampanju radi promidžbe vlastitih dostignuća. Svakodnevni bilteni, projekcije filmova, kolportaža literature, nastava engleskoga jezika i izložbe bili su, izvještavao je konzul Čehoslovačke, sredstvo za stjecanje povjerenja osobito među studentima i inteligencijom. S druge strane diplomatski predstavnik iz Praga govorio je o skromnim mogućnostima promidžbe i plasiranja kulturnih dostignuća komunističkih zemalja. Navodio je da su kontakti s češkom manjinom otežani, a društva nacionalne manjine Čeha odbojno su se odnosila prema konzulatu Čehoslovačke. Sa žaljenjem je govorio o malom interesu za literaturu komunističkih zemalja dostupnu u samom Zagrebu i zanemarivoj razini njezine dostupnosti u ostalim dijelovima Hrvatske. Kao primjer mogućnosti propagande zemalja istočnoga bloka naveo je veliki uspjeh nastupa baletne trupe iz Lenjingrada u Zagrebu 1958. godine. ${ }^{53}$

Tijekom različitih kulturnih manifestacija Sovjeti su pratili kulturna zbivanja i njihov ideološki sadržaj u Jugoslaviji i samoj Hrvatskoj. Na filmskom festivalu u Puli od 27. srpnja do 2. kolovoza 1962. bili su S. A. Gerasimov i T. E. Makarova. Njihov je dojam bio da je jugoslavenska kinematografija okrenula leđa Zapadu i sve više težila realizmu. Smatralo se: „Na ovom tlu 2-3 filma mladih redatelja ekstremnih pogleda izgledala su više kao izraz potrage nego izraz glavnih tokova razvoja kinematografije." Među spomenutim filmovima posvećena je pozornost filmu Kapi, vode, ratnici u režiji čuvenoga Živojina Pavlovića, vezanog uz crni val, Marka Bapca i Vojislava „Kokana” Rakonjca. Naglašeno je navodno negodovanje deset tisuća gledatelja, koji su zahtijevali njegov prekid. Opći je dojam Sovjeta sveden na zaključak da je umjetnička razina znatno porasla, a s najvećim odobravanjem gledalo se na filmove Surogat Dušana Vukotića, Kozara Veljka Bulajića, Tri Ane Branka Bauera ili Čudna devojka Jovana Živanovića. Iako su jugoslavenski umjetnici s ogorčenjem i negodovanjem govorili o zapadnoj kinematografiji, izražavali su nezadovoljstvo i u pogledu nabavke jugoslavenskih filmova od Sovexportfilma, smatrajući da su u SSSR-u birani drugorazredni filmovi. Filmski stvaratelji u Jugoslaviji zaključivali su da bi spomenuti filmovi Bauera i Živanovića bili posebno zanimljivi sovjetskoj publici. Sovjetski predstavnici u Puli izvještavali su da su planirani posjet Brežnjeva Jugoslaviji i povoljan tijek međusobnih državnih odnosa dobra prilika za jačanje kulturne suradnje, u okviru koje se može organizirati razmjena filmova i rasprave ljudi vezanih uz kinematografiju. ${ }^{54}$

Kremlj je kulturnim manifestacijama težio izgradnji svojega prestiža u svijetu i ideološkom prodoru. Zbog navedenog u sovjetskom ministarstvu kulture sa zadovoljstvom je primljen poziv na sudjelovanje u Muzičkom biennalu Zagreb u svibnju 1963. godine. Na osnovi depeša iz veleposlanstva

53 RU-РГАНИ, ф. 5, оп. 49, д. 122, Б. Ф. Сухомлинов, Запись беседь с консулом Чехословакии в Загребе Мали, 21 апреля 1958, 39-40.

54 RU-РГАНИ, ф. 5, оп. 49, д. 517, Е. Иванов, Зам. Председателя Союза Советских обществ дружбы, О поездке на IX фестиваль югославских фильмов в г. Пуле., Отчет о поездке в Югославию, 128-129. 
u Jugoslaviji, ministrica kulture Jekaterina Furceva izvještavala je Centralni komitet KPSS-a da bi sudjelovanje sovjetskoga ansambla - u ministarstvu se upućivalo na Simfonijski orkestar Moskovske državne filharmonije predvođen dirigentom svjetskoga glasa Kirilom Kondrašinom - kao i kolportaža informativnoga materijala poput informacija o sovjetskoj glazbi, dobro utjecalo na sovjetski ugled u samoj Hrvatskoj. Ovo posljednje može se razmatrati kao posebno važno u vezi sa slabom prisutnosti Sovjeta u jugoslavenskim republikama osim u glavnom gradu. Pismo Furceve dobilo je odobrenje šefa Komisije za veze s komunističkim i radničkim partijama socijalističkih zemalja Jurija Andropova i Dmitrija Polikarpova, pročelnika Ideološkoga odjeljenja Centralnoga komiteta KPSS-a. O dolasku sovjetske filharmonije u Zagreb razgovaralo se još ujesen 1962., kad je u Beogradu u sovjetskom veleposlanstvu primljen istaknuti skladatelj i dirigent Milko Kelemen, utemeljitelj (1961.) jednoga od najvažnijih glazbenih festivala - Muzičkoga biennala Zagreb. Kelemen je naglasio da bi rado primili sovjetske umjetnike, prije svega dirigenta svjetskoga glasa Arama Hačaturjana i skladatelja Andreja Eshpaia, kao i predstavnike Moskovske filharmonije. Što je zanimljivo, Kelemen je smatrao da bi gostovanje istaknutih sovjetskih umjetnika moglo pridonijeti slabljenju fascinacije apstrakcionizmom, umjetničkim žanrom koji je u samom SSSR-u izazivao nezadovoljstvo vlasti. ${ }^{55}$ Vrijedi napomenuti da je prvi sekretar Centralnoga komiteta KPSS-a tijekom posjeta izložbi prilikom 30. obljetnice Moskovskoga saveza umjetnika u prosincu 1962. pobjesnio zbog niske razine vlastite umjetničke spoznaje te s negodovanjem govorio o „patološkim čudovištima duhovno siromašnih umjetnika” i pokrenuo cijelu kampanju protiv umjetničkih sloboda u SSSR-u. ${ }^{56}$

Pojave u kulturi praćene su i tijekom V. kongresa Saveza dramaturga Jugoslavije, koji se održavao u Splitu 3. - 15. srpnja 1965. godine. Sa sovjetske strane bio je prisutan zamjenik ravnatelja Kazališta M. N. Jermolove, čuveni redatelj V. Komisaržejevskij. Promatrajući zbivanja u glavnom gradu Dalmacije, zaključio je da postoji opća sklonost umjetnika prema modernizmu te zapadnim uzorima, što je bilo vidljivo u njihovim umjetničkim opisima ondašnjih društvenih prilika u Jugoslaviji. Sovjetski redatelj negodovao je zbog dodjele nagrade „Marin Držić” pjesniku Borislavu Mihajloviću na Marulićevim danima, koji je u drami Strahinja Banović predstavio analizu univerzalnoga problema morala u državnom i društvenom životu. S neskrivenim divljenjem Komisaržejevskij se odnosio prema Dubrovačkim ljetnim igrama, prije svega zbog originalnoga načina prikazivanja spektakla na otvorenom, što je - podsjetio je - imalo svoju tradiciju i u SSSR-u u prvim godinama nakon boljševičke revolucije. Zaključivao je da bi takav način na-

55 RU-РГАНИ, ф. 5, оп. 49, д. 517, Ю. Андропов до ЦК КПСС, 21 IX 1962, Е. Фурцева, Министр культуры СССР до ЦК КПСС, С. Маслов, П-й секретар СССР в СФРЮ, Запись беседы с югославским композитором М. Келеманом, 11 августа 1962 г., 117-119, 121.

56 АКСЮТИН, Хрущевская „оттепель” и общественные настроения в СССР, 387389. 
stupa kazališnih umjetnika bio pogodan za privlačenje svjetske pozornosti na zbivanja u SSSR-u. ${ }^{57}$

Sovjeti su poistovjećivali zapadni utjecaj u kulturi s pojavom „liberalizma”, kako je u razgovoru sa savjetnikom veleposlanstva Kiseljevim rekao sekretar za pitanja kulture u Centralnom komitetu SK Jugoslavije Miloš Nikolić. Nikolić je tvrdio da je suzbijanje pojava „liberalizma” u kulturi, filmu i filozofiji te sociologiji bio jedan od najvažnijih zadataka SK Jugoslavije uoči VI. kongresa Partije. Jugoslavenski službenik naglasio je da je pitanje nacionalizma kao kulturološkoga i društvenoga problema bilo osobito uočljivo upravo u SR Hrvatskoj. S negodovanjem je priznao sovjetskom sugovorniku da se brojni ljudi iz kulture „Vode isključivo prema estetičkim kriterijima” u pogledu promidžbe određenih struja u umjetnosti. Naveo je uredništva časopisa u Ljubljani i Zagrebu kao glavne centre koji su navodno promicali liberalne zapadne vrijednosti. Usto je spomenuo filozofe poput Mihajla Markovića, sa žaljenjem govoreći o njemu kao čovjeku koji se herojski iskazao tijekom Drugoga svjetskog rata, a u tadašnjoj situaciji nije znao razlikovati „što je bijelo a što crno". 58

Upravo grupa Praxis, čiji je član Marković bio, naišla je na najkritičniji istup Nikolića, koji je susrete Korčulanske ljetne škole, kao i znanstveni skup u Novom Sadu Marks i suvremenost okarakterizirao kao antisocijalističke. Sovjeti su bili zainteresirani za aktivnost čuvenih znanstvenika koji su kritički preispitivali marksizam, u mnogim razgovorima pokretali su pitanje njihovih tekstova i neblagonaklono se odnosili prema sadržaju časopisa Praxis. Priznao je pritom da vlasti još uvijek nisu uspjele odrediti način suzbijanja takvih pojava jer su se plašile da bi žestoke metode mogle pogodovati „etatističkoj grupi" ${ }^{59}$ U razgovoru I. Kiseljeva s ravnateljem Instituta društvenih znanosti Najdanom Pašićem Pašić ga je pokušavao uvjeriti da je znanost u Jugoslaviji na najvišoj razini, a znanstvenici u svojem radu pokušavaju shodno političkim prilikama upozoriti na proturječnosti između centralizma i decentralizacije, raspodjele dohodaka, usavršavanja samoupravnoga sistema. Kiseljev se osvrnuo na pitanje djelovanja Praxisa i prigovorio da je ta grupa u jednom od zbornika iz 1964. izbjegavala kritiku „buržoaske ideologije” iz pozicija marksizma i lenjinizma. Po mišljenju Kiseljeva, radovi praksisovaca nisu naišli na kritiku organa vlasti. Pašić je priznao da su spomenuti filozofi i sociolozi dobili zapadne stipendije, među ostalim stipendiju Forda, a inge-

57 RU-РГАНИ, ф. 5, оп. 49, д. 517, В. Горшков, Заместитель Председателя Президиума Союза советских обществ дружбы и культурной связы с зарубежными странами до ЦК КПСС, 31 УШ 1965 г., В. Комисаржеевский, Вице-президент театральной секции СОД, режиссер Театра им. М. Н. Ермоловой, Отчет о поездке на 5-й Конгресс драматических артистов Югославии в Сплите, 3-15 юла 1965 г., 144, 147.

58 RU-РГАНИ, ф. 5, оп. 49, д. 711, И. К. Киселев, советник посольства СССР в СФРЮ, Запись беседы с секретарем идеологической комиссии ЦК СКЮ по вопросам культуры и науки М. Николичем, 23 октября 1964 г., 240-241.

59 Isto, 241. O značaju Praxisa i odnosu vlasti prema tom krugu intelektualaca vidi npr.: MIHALJEVIĆ, Komunizam i čovjek, 41, 516. 
rencije komunističkih vlasti u pitanju izbora stipendista bile su ograničene. Naveo je: „Vi naravno čitate zagrebački časopis 'Praxis' i vidite da se u njemu objavljuju različiti članci pogrešnoga karaktera koje piše određena grupa koja smatra da bi upravo ona trebala igrati vodeću ulogu u razvoju društvenih znanosti. U ovo vrijeme jasno je da se umjesto buržoaske ideologije kritizira socijalistička, a ovi ljudi pod svakakvim izgovorima teže ukazati na slabosti i nedostatke nove Jugoslavije. To se objašnjava time da je naša zemlja otvorena svima i ovdje je utjecaj buržoaske ideologije vrlo velik zbog velikih mogućnosti. Sve to promovira se naravno u vidu slobode stvaralaštva, eksperimenta i sl." Kiseljev se pozitivno odnosio prema Pašićevim stavovima, tvrdeći da bi se njegovo putovanje u SSSR planirano za 1966. moglo iskoristiti za promidžbu sovjetskih dostignuća. ${ }^{60}$

O „prevratničkoj” ulozi Praxisa govorila je i Stanka Veselinov, predsjedateljica Komiteta za prosvjetu i kulturu Saveznoga vijeća Savezne skupštine, koja je navodeći imena Milana Kangrge, Rudija Supeka i Predraga Vranickog priznala da ta grupa sebe smatra nadležnom u odnosu na SK Jugoslavije za pitanja filozofije marksizma. Po njezinim riječima, spomenuti filozofi htjeli su se nametnuti kao vodeća snaga u ideološkom oblikovanju sustava, a Partiji je trebala pripasti jedino uloga provođenja njihovih teorija. Rekla je da se Partija ipak iskazala odlučnošću i pred Ideološkom komisijom SK Jugoslavije objasnila je grupi Praxis da se ne smiju nametati kao superiorni u pitanju ideologije. ${ }^{61}$

S mnogo više odobravanja o djelovanju Praxisa govorio je prof. Malik Mulić sa slavističke katedre Sveučilišta u Zagrebu. Rekao je da njihova kritika staljinizma doduše jest prikrivena kritika jugoslavenskoga sustava, u kojem je nasljeđe staljinizma bilo veće nego bilo gdje drugdje, no negirao je tvrdnje o tobožnjem antisocijalističkom karakteru Praxisa, iznoseći da je jedino Rudi Supek prije bio isključen iz SK Jugoslavije. ${ }^{62}$

Sredinom 60-ih godina tadašnji problemi jugoslavenskih komunista $\mathrm{u}$ oblasti kulture bili su predmet razgovora sa spomenutom Stankom Veselinovom. U vezi s tekstovima Mihajla Mihajlova „Moskovsko ljeto 1964.” u časopisu Delo ili nadrealista Marka Ristića Veselinova je tvrdila: „nužni su određeni vidovi kontrole i napor vodećih krugova u ideološkom radu, jer ako se obuća i odjeća može proizvoditi samostalno, u ideološkim pitanjima ne može se računati na samostalnost, ne valja da mihajlovi i ristići šire ono što žele, što im se sviđa, vrijeđajući cijelo društvo." Društvo se u ideološkom pogledu, po

60 RU-РГАНИ, ф. 5, оп. 49, д. 808, И. К. Киселев, советник посольства СССР в СФРЮ, Запись беседы с директором Института общественных наук Найданом Пашичем, 27 марта 1965 г., 31-33.

61 RU-РГАНИ, ф. 5, оп. 49, д. 809, И. К. Киселев, советник посольства СССР в СФРЮ, Запись беседы с председательем Комитета по вопросам провещения культуры Союзного веча союзной Скупшины Станкой Веселиновой, 18 июня 1965 г., 102.

${ }_{62}$ RU-РГАНИ, ф. 5, оп. 49, д. 875, Запись беседы с проффесором кафедры славянских языков Загребского университета М. Муличем, 28 января 1966 г., 35. 
riječima Veselinove, trebalo oblikovati i uvođenjem tečaja marksizma i lenjinizma na svim fakultetima, a ne kao dotad samo na humanističkima. U tom pogledu odlučeno je da se umjesto udžbenika Svete Lukića uvede onaj Miroslava Pečulića, koji nije imao toliko grešaka. ${ }^{63}$

Veselinova je s odobravanjem gledala na samostalni razvoj kulture pojedinih nacija, govoreći s negodovanjem o tobožnjem stvaranju općejugoslavenske kulture. Tvrdila je da bi takav potez mogao stvoriti osjećaj poniženja kod manjih naroda i narodnosti poput Makedonaca ili Mađara. S druge strane osuđivala je reviziju povijesti „počevši od Nemanjića” i preveliko isticanje vlastitih povijesnih ličnosti u svakoj od jugoslavenskih nacija. ${ }^{64}$

\section{Zaključak}

Događaji u Jugoslaviji i samoj Hrvatskoj bili su praćeni u sovjetskim diplomatskim krugovima. Međusobni odnosi, nepovjerenje sovjetskih političara prema Titu i jugoslavenskom komunizmu u vidu samoupravljanja utjecali su na percepciju događaja u Jugoslaviji, osobito u razdoblju prijepora oko programa SK Jugoslavije sa VII. kongresa i samita komunističkih partija 1957. i 1960. godine. Veliki teret bila su upravo ideološka pitanja jer se u Moskvi u drugoj polovini 50-ih godina Jugoslaviju određivalo kao „revizionističku državu", što je izravno iskazano upravo na samitima komunističkih partija 1957. i 1960. U diplomatskim izvještajima sovjetskih izaslanika naglašavane su pojave na političkom, društvenom i kulturnom planu kojima je jugoslavenska stvarnost znatno odudarala od one u istočnom bloku. U slučaju Hrvatske Sovjete je zanimala primjena odluka federalnih vlasti na republičkom tlu.

Odstupanje od sustava sovjetskoga tipa primjećivalo se i u društvenom životu, gdje su Sovjeti glavnu pozornost posvećivali nacionalnom pitanju. Smatralo se da su jugoslavenski komunisti u pitanju nacionalnoga našli rješenja nakon 1945. tijekom učvršćivanja vlastite dominacije. Diplomatski predstavnici SSSR-a smatrali su da borba protiv nepismenosti i isticanje posebnosti nacija poput Makedonaca pridonosi njihovoj popularnosti i dokida postojeće animozitete. Zahtjeve pojedinih republika za veću samostalnost tretiralo se kao uobličenje nacionalizma, rastućih „egoizama” koji su narušavali „već riješeno nacionalno pitanje”. Ustvari su se optužbe svodile na samu srž jugoslavenskoga komunizma, koji - smatralo se u Kremlju - zbog „lutanja” za vlastitim rješenjima nije bio u stanju obuzdati unutarnje probleme na način tipičan za SSSR.

$\mathrm{Na}$ kulturno-društvenom planu razne publikacije u tisku kao i znanstveni radovi filozofa, pisaca ili povjesničara izazivali su negodovanje Moskve. Upravo se u Hrvatskoj u okviru Korčulanske ljetne škole djelovanjem filozofa u krugu

63 RU-РГАНИ, ф. 5, оп. 49, д. 809, И. К. Киселев, советник посольства СССР в СФРЮ, Запись беседы с председательем Комитета по вопросам провещения культуры Союзного веча союзной Скупщины Станкой Веселиновой, 103-104.

${ }^{64}$ Isto, 103. 
Praxisa razvila jedna kritička misao prema postojećem stanju u Jugoslaviji, koju su ljudi poput Gaje Petrovića smatrali opterećenom nasljeđem staljinizma.

Iako su Sovjeti bili usredotočeni na zbivanja u centru države, nisu bili ravnodušni prema onome što se događalo i izvan Beograda. Uočljivo je da su Sovjeti svojom prisutnošću znatno zaostajali za zapadnim državama što se tiče zastupljenosti u ostalim jugoslavenskim republikama. Iako kritični prema raznim strujama u jugoslavenskom filmu, književnosti i tisku, Sovjeti su težili svojom prisutnošću u NR/SR Hrvatskoj na raznim kulturnim događajima doprijeti do širih slojeva društva.

Premda se na kulturnom i gospodarskom planu pokušavalo propagandnim sredstvima poput izložaba na Zagrebačkom velesajmu, kolportaže brošura i publikacija poslanih iz Moskve stjecati ugled u društvu, dominacija zapadne promidžbe u Hrvatskoj bila je nedvojbena, a utjecaj istočnoga lagera prilično slab.

\section{Arhivski izvori}

RU-РГАНИ, ф. 5, оп. 49: Rusija, Российский государственный архив новейшей истории, фонд 5, Аппарат ЦК КПСС, опись 49, Отдел ЦК КПСС по связям с коммунистическими и рабочими партиями социалистических стран. февраль 1957 г. - апрель 1966 г. (Rusija, Ruski državni arhiv novije povijesti, fond 5, Aparat Centralnoga komiteta KPSS-a, akta 49, Komisija za veze s komunističkim i radničkim partijama socijalističkih zemalja, veljača 1957. - travanj 1966.).

SR-AJ-507-CKSKJ: Srbija, Arhiv Jugoslavije, fond 507, Centralni komitet Saveza komunista Jugoslavije.

\section{Objavljeni izvori}

PETRANOVIĆ, Branko; ZEČEVIĆ, Miodrag, prir. Jugoslavija 1918-1988. Tematska zbirka dokumenata. Beograd: Rad, 1988.

\section{Literatura}

AKMADŽA, Miroslav. Katolička crkva u komunističkoj Hrvatskoj 1945. 1980. Zagreb; Slavonski Brod: Despot Infinitus; Hrvatski institut za povijest, Podružnica za povijest Slavonije, Srijema i Baranje 2013.

АКСЮТИН, Юрий. Хрущевская „оттепель” и общественные настроения в СССР в 1953-1964 г2. Москва: РОССПЕН, 2004.

АНИКЕЕВ, Алексей Семенович, ur. Москва и Восточная Европа. Советско-югославский конбликт и страны советского блока, 1948-1953 22. Очерки истории. Москва; Санкт Петерсбург: Нестор; История, 2017.

DIMIĆ, Ljubodrag, ur. Jugoslavija - SSSR. Susreti i razgovori na najvišem nivou rukovodilaca Jugoslavije i SSSR, tom 1: 1946-1964. Beograd: Arhiv Jugoslavije, 2014. 
DIMIĆ, Ljubodrag. Jugoslovensko-sovjetski odnosi 1945-1956. Zbornik dokumenata. Beograd: Ministarstvo spoljnih poslova Republike Srbije; Ministarstvo spoljnih poslova Ruske Federacije, 2010.

DIMIĆ, Ljubodrag. „Jugoslovensko-sovjetski odnosi 1953-1956: zbliženje, pomirenje, razočarenje”. U: Jugoslovensko-sovjetski sukob 1948. godine. Zbornik radova., ur. Petar Kačavenda. Beograd: Institut za savremenu istoriju, 1999, 279-293.

ЕДЕМСКИЙ, Андрей Борисович. „Нормализация отношений с СССР (март 1953 г. начало 1960-х годов)“. U: Югославия в XX веке: Очерки политической истории, ред. Константин Владимирович Никифоров, Москва: Индрик, 2011, 661-682.

ЕДЕМСКИЙ, Андрей Борисович. От конфликта к нормализаиии: советско-югославские отношения в 1953-1956 годах. Москва: Наука, 2008.

MIHALJEVIĆ, Josip. Komunizam i čovjek. Odnos vlasti i pojedinca u Hrvatskoj od 1958. do 1972. Zagreb: Hrvatski institut za povijest, 2016.

MIHALJEVIĆ, Josip. „Ustavna uređenja temeljnih prava u Hrvatskoj 1946. - 1974." Časopis za suvremenu povijest 43 (2011), br. 1: 25-51.

MILORADOVIĆ, Goran. Lepota pod nadzorom. Sovjetski kulturni uticaji u Jugoslaviji 1945-1955. Beograd: Institut za savremenu istoriju, 2012.

НАГОРНАЯ, Оксана С. „'Витрыны споветских достижений’ СССР на международных выставках товаров народного потребления". U: Оксана С. Нагорная, Советская культурная дипломатия в условиях Холодной войны 1945-1989. Москва: РОССПЕН; Политическая Енциклопедия, 2018, 86-95.

NEĆAK, Dušan. Hallsteinova doktrina i Jugoslavija. Tito između Savezne Republike Njemačke i Njemačke Demokratske Republike. Zagreb: Srednja Europa, 2004.

PELIKAN, Jan. Jugoslávie a východní blok 1953-1958. Praha: Univerzita Karlova v Praze, Nakladetelstvi Karolinum, 2001.

PLETERSKI, Janko; KECIĆ, Danilo; VASIĆ, Miroljub; DAMJANOVIĆ, Pero; TRGO, Fabijan; MORAČA, Pero; PETRANOVIĆ, Branko; BILANDŽIĆ, Dušan; STOJANOVIĆ, Stanislav. Povijest Saveza komunista Jugoslavije. Beograd: Izdavački centar Komunist; Narodna knjiga; Rad, 1985.

RADELIĆ, Zdenko. Hrvatska u Jugoslaviji 1945. - 1991. Od zajedništva do razlaza. Zagreb: Školska knjiga, 2006.

СТЫКАЛИН, Александр Сергеевич. „СССР-Югославия: зигзаги двусторонних отношений (вторая половина 1950-в - начало 1960-х годов)“, Славяноведение 2006, 3: 95-102.

TEBINKA, Jacek. Uzależnienie czy suwerenność? Odwilż październikowa w dyplomacji Polskiej Rzeczypospolitej Ludowej 1956-1961. Warszawa: Wydawnictwo Neriton; Instytut Historii Polskiej Akademii Nauk, 2011. 
TRIPKOVIĆ, Đoko. Jugoslavija-SSSR 1956-1971. Beograd: Institut za savremenu istoriju, 2013.

TYSZKIEWICZ, Jakub. Rozbijanie monolitu. Polityka Stanów Zjednoczonych wobec Polski 1945-1988. Warszawa: Wydawnictwo PWN, 2015.

VUČETIĆ, Radina. Koka-kola socijalizam. Amerikanizacija jugoslovenske popularne kulture šezdesetih godina XX veka. Beograd: Službeni glasnik, 2012. 


\section{SUMMARY}

\section{The Soviet View of the Events in Croatia and Yugoslavia in the Second Half of the 1950s and the Early 1960s}

The Soviet view of Croatia, as well as the situation in Yugoslavia, resulted from Soviet interests, its efforts to draw Yugoslavia into its orbit of influence. Particular reluctance was evident on the realm of ideology and purported Western influence, the effectiveness of which was exaggerated in the Soviet documents.

In the political dimension, the Kremlin was interested to which extent directives from the center were implemented at the republican level. The attitudes of local politicians toward the actions of the central authorities were also the matter of interest for Soviets. The fact that Croatia was the second richest republic and its aspiration for greater decision-making were regarded as negative phenomenon. Discussions about the competencies of the republics were depicted as closely tied to the national question, referring to the difficult experiences of the first half of the 20th century.

In the economic and cultural sphere, there was particular interest in the possibilities of cooperation and building up one's own influence in the Croatian SR. Despite the negative perception of many phenomena in Yugoslav culture, where a critical stance toward the USSR was expressed in film, literature, and the press, Moscow believed that through the presence of Soviet culture - often such as music and theater - it would be possible to gradually gain approval of the public sphere. The Kremlin's propaganda, however, was not as effective in Yugoslavia-as it was throughout the world-as it was in the West. The Soviets paid more attention to events in the center of the country, although they did not ignore regional events either.

Key words: Soviet Union; Croatia; Yugoslavia; ideology; culture; propaganda 